\title{
Principles of Critical Language Pedagogy: A literature review
}

Piosang, Tristan L. $\<$

National University-Manila, Philippines (piosangtl@gmail.com)

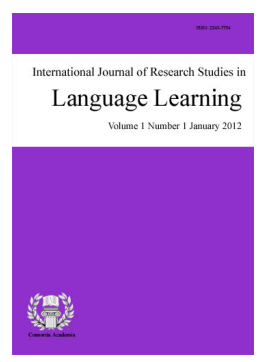

ISSN: $2243-7754$ Online ISSN: 2243-7762

\section{Abstract}

The present article enumerated and discussed some principles of Critical Language Pedagogy (CLP) through literature review. CLP is defined in this paper as an approach to language pedagogy where language teaching is a tool for developing learners who are (1) critically aware of social problems that emanate from oppression and injustice; and, (2) able to argue for solutions and counter-argue, hence triggering critical discourse in the classroom. There are six principles that were derived through literature review. These principles include: (1) Critical language pedagogy is a political process; (2) Critical language pedagogy is student-centered; (3) Critical language pedagogy makes classes as democratic public spheres, (4) Critical language pedagogy is highly dialogical, (5) Critical language pedagogy employs emancipatory authority, and (6) Critical language pedagogy is aimed at social transformation.

Keywords: critical pedagogy; critical language pedagogy; language pedagogy; authority; social transformation 


\section{Principles of Critical Language Pedagogy: A literature review}

\section{Introduction}

There have been extensive studies that discussed Critical Language Pedagogy or CLP (see Giroux, 1997; Freire, 1970, 1985, 1998; Sacadura, 2014; Santa-Williamson, 2000; Kanpol, 1998, Vandrick, 1994). Generally, these studies have either delved into the theoretical grounding of CLP or analyzed the concept in juxtaposition, to power, authority, and democracy. While these studies discussed the concept with much theoretical depth, what appears to be lacking are the established set of principles that characterize CLP. There is a necessity to establish a set of principles of CLP to synthesize all the conceptions and theories that have been posited on CLP, hence to create a clear set of essential characteristics that make up the concept. The absence of this set of principles may result to a confused and vague understanding of the concept. This paper, therefore, addresses the need to enumerate, describe and explain principles of CLP which were derived through a review of literature and studies (see Giroux, 1997; Freire, 1970, 1985, 1998; Sacadura, 2014; Santa-Williamson, 2000; Kanpol, 1998, Vandrick, 1994).

Critical language pedagogy (CLP) is an approach to language pedagogy where language teaching becomes a tool for developing learners who are (1) critically aware of social problems that emanate from oppression and injustice; and, (2) able to argue and propose solutions to these problems, consequently triggering critical discourse in the classroom. CLP is an offshoot of Critical Pedagogy (CP). CP emanated from Critical Theory (CT) which was developed by the philosophers and theorists of the 1923 Frankfurt School of Thought like Adorno, Habermas, and Marcuse, to name a few (Aliakbari \& Faraji, 2011). Any discussion on CLP necessitates a sufficient discussion on CT to better understand the theoretical grounding and historical background of the concept.

CT deals with the idea of attaining a just society where citizens enjoy political, economic, and cultural control of their lives (Aliakbari \& Fajari, 2011). CT takes its main theoretical grounding on Marxist thought where it is posited that the capitalist-elites control power in the society which they take away from the masses or the working class, hence making the former as the oppressor and the latter as the oppressed. This theory is known as the Conflict Theory. The oppressor-oppressed relationship, so to speak, presupposes that the oppressed are not able to enjoy political, economic, and cultural control of their lives because of the oppressors' strong control of political, economic, and cultural powers in the society. Hence, there are social inequalities and social injustices experienced and committed to the oppressed. CT, therefore, presents a societal problem which necessitates action from the oppressed or the masses.

As response to this Marxist analysis of the oppressed-oppressor relationship and its call for social action, several responses were proposed to address oppressions and injustices, hence to take back the control of power from the elite class to the masses. One of these responses is the Marxist-Leninism of the Soviet Union which advocated for the concept of a vanguard party that rules under a one-party state. On the other hand, the Maoist action - that which was conceptualized by the Chinse leader Mao Zedong - puts mass armed struggle of the peasantry and of the working class as central to the attainment of a society where citizens are truly free from the oppressions by the elite. While both of these schools of thought - Leninist and Maoist - have had tremendous impact on national and international politics and economics, their being able to actually address the problem posed by CT has not yet been established. For one thing, the vanguard party of the Soviet Union was relatively ineffective as it had been dissolved in 1989.

CP was perceived to be the realization of the CT of the Frankfurt School. Marcuse argued that instead of the process of schooling serving as free space for intellectual discourse, it withholds opportunities for learners to think independently, formulate their own ideas, and "essentially de-skill students (Breuing, 2011; Apple, 1982; 
Kincheloe, 2014). The theorists of Frankfurt argued schools espouse dependency of learners to teachers and hierarchical understanding of authority which undermine the kind of social consciousness that change and social transformation necessitates (Breuing, 2011; Eisner, 2002).

To this, Brazilian philosopher Paulo Freire responded through developing the concept of the Pedagogy of the Oppressed. Freire is regarded as the inaugural philosopher of CT (Breuing, 2011). In his works, Freire argued for the need of an emancipatory model of education as he understood, coming from his background as educational worker for the poor and the marginalized in Brazil, that schools had become impediments to the education of the poor (Freire, 1970; Breuing, 2011). According to Breuing (2011), this realization made Freire "argue that people need to engage in a praxis that incorporates theory, action, and reflection as a means to work toward social change and justice (p. 4)." Hence, he developed the idea of CP which would serve as response to marginalization and oppression.

Several theorists have also proposed their conceptions of CP and its goals. For Vandrick (1994), the major goal of $\mathrm{CP}$ is to emancipate and educate all people regardless of their gender, class, race, and many others. (Aliakbari \& Faraji, 2011). Kanpol (1998), on the other hand, argued that CP is founded on the belief that citizens ought to have an education which involves understanding the schooling structure by the teacher that would not permit education to ensue. Meanwhile, Gadotti (1994) inferred that the works of Freire on CP seek to change the structure of an oppressive society.

In general, all these studies suggest that CLP is a political approach in language teaching that, in the course of teaching the language, confronts social issues (i.e. social injustice and forms of oppression) in an attempt to address them. Furthermore, through a review of these literature and studies, some principles that make up CLP are derived. These principles are CLP's essential characteristics and are therefore fundamental to the understanding of the concept.

\section{Discussion}

There are six principles that constitute CLP, namely: (1) Critical language pedagogy is a political process; (2) Critical language pedagogy is student-centered; (3) Critical language pedagogy makes classes as democratic public spheres, (4) Critical language pedagogy is highly dialogical, (5) Critical language pedagogy employs emancipatory authority, (6) Critical language pedagogy is aimed at social transformation. These principles explain the essential characteristics of CLP as posited in the various studies that have been reviewed (see Giroux, 1997; Freire, 1970, 1973, 1985; Sacadura, 2014; Santa-Williamson, 2000; Kanpol, 1998, Vandrick, 1994).

\subsection{Critical language pedagogy is a political process}

McLaren (1989) argues that the major concern of critical pedagogy in general is the centrality of politics in the understanding of the school system. This is one of the bases for the first principle of CLP: pedagogy is political. It upholds that language learning and language teaching are political processes that occur in a political setting, i.e. the school. This is contrary to traditional view of pedagogy as apolitical and is ought to be such. This principle is actually considered as the most important theme in critical pedagogy (Aliakbari \& Farji, 2011; Freire, 1970, Freire \& Macedo, 1987; Giroux, 1997; Shor, 1992).

The term political in this principle has to be qualified because it has varied definitions and conceptions. Political, in this discussion of CLP, refers to the "pattern of human relationship that involves, to a significant extent, power, rule, or authority" (Dahl, 1991, p. 4). This ideates that the recognition of language pedagogy as political and the school system as a political structure entails the recognition of the presence of power and authority in the classroom.

In reference to Conflict Theory, one of the theoretical assumptions in CLP, where there is power and authority, there is a contestation among classes to gain control of these social categories. This holds true in 
language classes. To illustrate: there are two contesting classes in the classroom. These classes are (1) the teacher and (2) the learners. In traditional language classes - or that which subscribes to the traditional view of education - the teacher controls the power and authority in the class. The learners, on the other hand, act as receivers or objects of power and authority. In this kind of set-up, the oppressor-oppressed relationship is demonstrated - the teacher being the oppressor and the learners being the oppressed. The teacher becomes the oppressor because he acts as the sole repository of knowledge. He controls class discussion and enjoys the prerogative to choose who to recognize to speak in class discussions or, in extreme cases, may opt not to entertain any thoughts at all from the learners. It must be noted that the oppressor-oppressed relationship does not only exist on the condition that someone is deprived economically or physically by the ruling class. Such kind of relationship exists in all circumstances, in all societal units and political structures, where one class monopolizes power and authority - in whatever form they take - making other classes deprived of anything that is rightfully and justly theirs. In this illustration, since the monopoly of power and authority is enjoyed by the teacher, it is most possible that democratic rights of the learners to speak out and participate in class discussions are curtailed.

In recognition that language pedagogy is a political process, CLP makes the classroom a platform for free and open space for critical discourse. It is one where, in the course of studying the language, socio-political issues are discussed most especially by the learners guided by the teacher. This principle also affirms the notion that language learning theory and teaching should pay its focus on larger sociohistorical and political forces found in the social identities of people who use them (Hall, 1995; Aliakbari \& Faraji, 2011). It veers away from the traditional notion of language teaching as merely the teaching of grammatical function and structures of language devoid of any socio-political relevance.

\subsection{Critical language pedagogy is student-centered}

In the discussions on the preceding principle, the traditional view of education was alluded to. It is one where the teacher acts as the sole repository of knowledge, and the sole controller of authority and power in the classroom. This traditional view of education is also called teacher-centered approach. CLP takes exactly the opposite of this approach, i.e. the student-centered approach. This makes up the second principle: CLP is student-centered.

A CLP classroom is a student-centered learning environment. A student-centered learning environment is one where (1) teachers recognize their role as facilitators of learning, and (2) teaching approach veers away from merely conveying knowledge towards facilitating students' personal discovery of knowledge through critical class discussions and mentoring. Student-centeredness is a crucial feature of CLP. Without the employment of this approach, the existence of a classroom as a democratic space for critical discourse would be impossible. Learners would be given enough opportunities to think about to share and argue their insights in the class.

Furthermore, this principle affirms that at the heart of CLP are the learners given enough space and opportunity to exercise their democratic rights and academic freedom inside the classroom. When they are given this opportunity, it is most likely that they will develop awareness of socio-political issues, since it is expected of a CLP teacher to propound questions that would trigger socio-political discussions. Their constant engagement in such critical discussions would harness their critical thinking skills. Also, in the course of these discussions, learners are also encouraged and are actually able to propose solutions on socio-political problems, hence making themselves contributors to social transformation.

\subsection{Critical language pedagogy makes classes democratic public spheres}

The third principle proposed in this paper is that CLP makes schools as democratic public spheres. This principle is mainly founded on Giroux's conception and discussions on CP. In order to better understand this principle, there is a need first to sufficiently discuss the key construct in the principle, i.e. the public sphere. The 
construct public sphere was introduced by the philosopher Jurgen Habermas, also a scholar on critical theory and one of the thinkers of Frankfurt School. It was Giroux $(1985,1997)$ who often alluded to Habermas's public sphere in his conception of critical pedagogy. Hence, Giroux takes the credit of formally introducing public sphere in the discussion of critical pedagogy. Habermas (1962) explained the public sphere as a society engaged in a critical public debate with following conditions:

$>$ The formation of public opinion.

$>$ All citizens have access.

$>$ Conference in unrestricted fashion (based on the freedom of assembly, the freedom of association, the freedom to expression and publication of opinions) about matters of general interest, which implies freedom from economic and political control.

$>\quad$ Debate over the general rules governing relations.

Basically, public sphere is a socio-political entity where citizens are engaged in a free and critical public discourse about societal problems which leads to cause political action and social transformation. By this definition, the relevance of public sphere to CLP can be drawn. CLP paves way for language classes that transform the classroom into a democratic space for critical discourse among the learners. Hence, when this is realized and language classes become truly an avenue for critical discourse on socio-political issues among learners, public sphere is created. In the course of realizing CLP in a language class, the conditions of public sphere are being met. CLP, therefore, facilitates the transformation of a typical language class into a democratic public sphere.

\subsection{Critical language pedagogy is dialogical}

In arguing that CLP facilitates the transformation of language classes into a democratic public sphere, it is presupposed that learners, when the transformation has been realized, are given the opportunity to discuss and argue freely in the class. Hence, the fourth principle: CLP is highly dialogical.

The success of CLP lies mainly on the instructional technique of the teacher. CLP, as it aims at developing socio-political awareness of learners, requires a highly dialogical instructional technique. By this, it is meant that in CLP, language teachers ought to emphasize and maximize the utilization of dialogue and discourse in the class. For a case scenario, take for example an English 10 class in the Philippines where the topic is writing argumentative essay. In teaching writing argumentative essay, the teacher will randomly ask the students of what pressing socio-political issues they feel they are concerned with or that which they feel relevant to them. The teacher will list down the answers given by the learners. After giving their thoughts, the teacher will ask the class of which among the issues or problems they have given they feel relevant to them. For instance, what was unanimously chosen by the class is the implementation of the $\mathrm{K}$ to 12 education reform program of the Philippine government (political issue/problem). The teacher will then facilitate a free and critical class discussion by giving equal opportunity to the learners to speak out and argue for or against the proposition. After sufficient discussion, the teacher will then make connections between what the class did (i.e. class argumentation/discussion) and the lesson. This is an instance where CLP becomes highly dialogical for it employs dialogue and discourse as an instructional technique. It is also only through dialogue or classroom discourse where learners are given the opportunity to openly and freely share their thoughts and display critical thinking. The dialogical feature of CLP is a necessary factor to the transformation of the language class into a democratic public sphere (Principle \#3).

\subsection{Critical language pedagogy employs emancipatory authority}

The common conception on authority is always negative and inimical to democracy. But, this conception neglects the notion that authority is perpetually present in all human organizations such as governments, even the 
democratic ones. One possible explanation for this common misconception is the misuse and abuse of authority in almost all stages of human political history which might have led to the association of authority to something evil. But, again, in discussions of political philosophy, the notion that authority is present so long as human organizations (or civilizations) exist holds stronger than the common notion that power is evil.

In CLP, a certain conception and form of power is employed, i.e. emancipatory authority. This makes up the fifth principle of CLP. Emancipatory authority is a concept and form of power introduced by Giroux (1997) which he discussed quite extensively in his book Authority, Intellectuals, and Politics of Learning:

"I want to broaden the definition of authority to include educational practices that link democracy, teaching and practical learning. The substantive nature of this task takes as its starting point the ethical intent of initiating the students into a discourse and a set of pedagogical practices that advances the role of democracy within the schools while simultaneously addressing those instances of suffering and inequality that the structure the daily lives of millions of people...”(p. 96).

In this discussion, Giroux (1997) argued for the possibility of a form of authority that aims at the strengthening of the democratic practices of schools. This form of authority relates the schooling to democracy and vice versa. This relationship was described by Giroux (1985) as "making the pedagogical more political, and the political more pedagogical" (p. 87). The concept of emancipatory authority, Giroux (1997) argues, makes teachers as "bearers of critical knowledge, rules, and values through which they consciously articulate and problematize their relationship to each other, to students, to subject matter, and to the wider community" (p. 103). This qualifies the kind of authority that teacher possess in the classroom. It is not that kind of authority that aims to monopolize knowledge and restrict the learners from reflecting, sharing and arguing their thoughts and beliefs.

\subsection{Critical language pedagogy is aimed at social transformation}

Ultimately, CLP is aimed at social transformation. At the heart of CLP is the transformation of a typical language class to one which is responsive to the issues and problems that hound the society these language learners are part of. It makes language learning more purposive as it attempts to make every language learning opportunity as also an opportunity to discuss and address socio-political issues. As CLP capitalizes on critical classroom discourse, learners are made to be highly aware of socio-political realities that surround them. With them being aware of these, they are triggered to reflect on these and think of possible solutions to them. CLP does not limit language learning to merely teaching the learners of the rudiments of the language, i.e. grammatical rules, literature, etc. CLP makes language learning more purposive for, in the course of teaching the rudiments of language, it also makes the classroom a platform for critical discussion ultimately aimed at contributing to social transformation, making language learners as active participants in the process of social transformation.

\section{Conclusion}

The present article enumerated, described, and explained some six principles of CLP through literature review. These principles are the following: (1) Critical language pedagogy is a political process; (2) Critical language pedagogy is student-centred; (3) Critical language pedagogy makes classes as democratic public spheres, (4) Critical language pedagogy is highly dialogical, (5) Critical language pedagogy employs emancipatory authority, (6) Critical language pedagogy is aimed at social transformation. The present article may have implications on understanding the CLP as a pedagogical concept. Specifically, the principles may serve as a guide on how teachers should implement CLP in the classroom. 


\section{References}

Aliakbari, M., \& Faraji, E. (2011). Basic principles of critical pedagogy. Retrieved from http://www.ipedr.com/vol17/14-CHHSS\%202011-H00057.pdf

Apple, M. (1982). Education and power. Boston: ARK Publications.

Breuing, M. (2011). Problematizing critical pedagogy. International Journal of Critical Pedagogy, 3(3), 1-23.

Dahl, R. (1957). The concept of power. Retrieved http://www.unc.edu/ fbaum/teaching/articles/Dahl_Power_1957.pdf https://doi.org/10.1002/bs.3830020303

Eisner, E. (2002). The educational imagination: On the design and evaluation of school programs (3rd ed.). New York: Macmillan.

Freire, P. (1970). The pedagogy of the oppressed. NY: Continuum.

Freire, P. (1973). Pedagogy of the oppressed. Baltimore: Penguin Books.

Freire, P. (1985). The politics of education: culture, power, and liberation. MA: Bergin \& Garvey. https://doi.org/10.1007/978-1-349-17771-4

Freire, P. (1998). Pedagogy of freedom: Ethics, democracy, and civic courage. New York: Rowman and Littlefield.

Freire, P., \& Macedo, D. (1987). Literacy: Reading the word and the world. Connecticut, United States: Praeger. Gadotti, M. (1994). Reading Paulo Freire: His life and work. NY: New York University Press.

Giroux, H. (1985). Critical pedagogy and the resisting intellectual - Part II. Phenomenology Pedagogy, 3(2), 84-97.

Giroux, H. (1997). Pedagogy and the politics of hope. CA, USA: Westview Press.

Habermas, J. (1962).The structural transformation of the public sphere: An inquiry into a category of bourgeois society. Cambridge: Polity.

Habermas, J. (1989). The structural transformation of the public sphere: An inquiry into category of bourgeois society. MA: The MIT Press.

Hall, J. K. (1995). (Re)creating our worlds with words: A sociohistorical perspective of face-to-face interaction. Applied Linguistics, 16, 206-232. https://doi.org/10.1093/applin/16.2.206

Kanpol, B. (1998). Critical pedagogy for beginning teachers: The movement from despair to hope. Retrieved from https://edu301s12.files.wordpress.com/2012/02/critical-pedagogy-for-beginning-teachers.pdf

Kincheloe, J. L. (2004). Critical pedagogy. New York, NY: Peter Lang.

McLaren, P. (1989). Life in schools: An introduction to critical pedagogy in the foundations of education. Routledge.

Sacadura, C. B. (2014). Philosophy of education, values and utopia in the critical pedagogy of Paulo Freire. European Scientific Journal, Special Ed, 498-505.

Santa-Williamson, E. (2000). Critical pedagogy in TESOL: A review of Literature. Retrieved http://files.eric.ed.gov/fulltext/ED447700.pdf

Shannon, P. (1992). Becoming political: Reading and writings in the politics of literacy education. New Hampshire: Heinemann.

Shor, I. (1992). Empowering education: Critical teaching for social change. Chicago, USA: University of Chicago Press.

Vandrick, S. (1994). Feminist pedagogy in EFL. College ESL, 4(2). 
Piosang, T. L. 